\title{
Narodowy Instytut Onkologii i Hematologii
}

\author{
Krzysztof Warzocha
}

Przedrukowano za zgodą z czasopisma Hematologia 2013, tom 4, nr 3, 185-196

W artykule przedstawiono projekt utworzenia krajowej sieci onkologicznej w oparciu o wielospecjalistyczne centra onkologii i instytuty, ze szczególnym uwzględnieniem roli i miejsca Narodowego Instytutu Onkologii i Hematologii.

\section{National Institute of Oncology and Hematology}

This article describes the project of a national network for oncology in Poland based on comprehensive cancer centres and institutes, in particular the role played by the National Institute of Oncology and Hematology.

NOWOTWORY Journal of Oncology 2013; 63, 5: 357-367

Słowa kluczowe: Narodowy Instytut Onkologii i Hematologii, wielospecjalistyczne centrum onkologii, onkologia, hematologia, certyfikat kompetencji, stopień referencyjności, nowotwory, profilaktyka, diagnostyka, leczenie Key words: National Institute of Oncology and Hematology, comprehensive cancer center, oncology, hematology, certificate of competence, referral levels, neoplasms, prevention, diagnosis, treatment

\section{Wprowadzenie}

W Europie z powodu nowotworów umiera około miliona osób rocznie, przede wszystkim w związku z zachorowaniami na nowotwory płuca, jelita grubego i piersi. Prognozy epidemiologiczne wskazują, że w najbliższej przyszłości liczba zgonów będzie wzrastać ze względu na starzenie się społeczeństw. W krajach Unii Europejskiej (UE) zauważa się istotne rozbieżności w zakresie jakości opieki nad chorymi na nowotwory oraz pod względem wyników leczenia. Wyniki raportu EUROCARE z 2004 roku wskazują, że liczba zgonów z powodu chorób nowotworowych w krajach Europy Środkowej i Wschodniej jest większa niż w Europie Zachodniej [1].

Podczas plenarnej sesji Parlamentu UE w 2007 roku określono podstawowe obszary działań w celu lepszej kontroli nad chorobami nowotworowymi, zwłaszcza zapobieganie, wczesne wykrywanie, skuteczniejszą diagnostykę i leczenie oraz opiekę paliatywną. Zgodnie z rekomendacjami Parlamentu UE państwa członkow- skie powinny dostosować działania w zakresie onkologii do najnowszych postępów naukowych, stymulować rozwój innowacyjności oraz badań naukowych nad nowotworami, zabezpieczyć ciągłość prowadzenia badań klinicznych i promować akcje informacyjne skierowane do ogółu społeczeństwa oraz do wszystkich podmiotów świadczących usługi zdrowotne [2].

Do najważniejszych czynników sukcesu w krajach o najlepszych wynikach rozpoznawania i leczenia nowotworów należą: organizacja systemu opieki onkologicznej na podstawie koncepcji wyspecjalizowanych, referencyjnych i certyfikowanych ośrodków o najwyższym standardzie kompetencji diagnostycznych i terapeutycznych; zapewnienie koordynowanej opieki, w której chory jest prowadzony „po systemie" zgodnie z opracowaną na wstępie strategią leczenia wielodyscyplinarnego, ze skróceniem do minimum czasu oczekiwania na rozpoznanie i leczenie; efektywne wykorzystanie zasobów i sprawny system monitorowania skuteczności leczenia, w tym prowadzenie rejestru zachoro-

Instytut Hematologii i Transfuzjologii w Warszawie

Centrum Onkologii — Instytut im. Marii Skłodowskiej-Curie w Warszawie 
wań na nowotwory z możliwością uzyskania dodatkowych informacji o stopniu zaawansowania choroby, zastosowanych metodach leczenia i wskaźnikach przeżywalności; stosowanie wytycznych diagnostyczno-terapeutycznych opartych na najlepszych wzorcach; ciągła edukacja kadr specjalistycznych i personelu medycznego oraz koordynacja realizacji tego kształcenia przez wytypowane placówki o najwyższym poziomie referencyjności; wysoka zgłaszalność w populacyjnych programach badań przesiewowych.

W krajach UE i w Stanach Zjednoczonych (USA, United States of America) głównym ośrodkiem realizującym światowe rekomendacje dotyczące wdrożeń i zaleceń krajowych w zakresie zapobiegania, wczesnej diagnostyki, skojarzonej terapii i opieki paliatywnej, wdrożenia najnowszych projektów naukowych i stymulowania rozwoju i innowacyjności badań naukowych, promocji informacji społecznych oraz koordynującym krajowe działania w wyżej wymienionych zakresach są narodowe instytuty nowotworów - precyzyjnie zdefiniowane organizacyjnie, administracyjnie, naukowo i klinicznie jednostki typu comprehensive research and clinical cancer center.

W zakresie działań kliniczno-naukowych narodowe instytuty współpracują z wielospecjalistycznymi centrami onkologicznymi (CCC, comprehensive cancercentre), wspólnie realizując — w ramach sieci lub konsorcjum — powyższe cele strategiczne na terenie danego kraju. Diagnostyka i leczenie w tych ośrodkach są prowadzone w oparciu o standardy diagnostyczno-lecznicze i realizowane przez wielodyscyplinarne zespoły (MDT, multidisciplinary team) zgrupowane narządowo (cancer units), czyli zapewniające leczenie i konsultacje w poszczególnych rodzajach nowotworów (np. nowotwory piersi, mięsaki, nowotwory hematologiczne i in.).

Tocząca się w kraju dyskusja nad strategią dla polskiej onkologii („Czas na onkologię") z pominięciem opinii i stanowisk przedstawicieli czołowych wielospecjalistycznych centrów onkologii (WCO), instytutów oraz onkologicznych towarzystw naukowych, w tym Polskiego Towarzystwa Onkologii Klinicznej (PTOK), Polskiego Towarzystwa Chirurgii Onkologicznej (PTCHO), Polskiego Towarzystwa Radioterapii Onkologicznej (PTRO), budzą uzasadniony niepokój i dezinformację środowiska, decydentów, pacjentów, pracodawców, a nawet producentów [3, 4]. W odpowiedzi na tę sytuację, w 2012 roku, z inicjatywy Ministerstwa Zdrowia, przy udziale ekspertów Centrum Onkologii — Instytutu (CO-I) im. Marii Skłodowskiej-Curie i konsultanta krajowego ds. onkologii, rozpoczęto prace nad rozwiązaniami organizacyjnymi umożliwiającymi utworzenie krajowej sieci onkologicznej mogącej się przyczynić do poprawy ogólnej jakości opieki onkologicznej i postępu wiedzy w walce z nowotworami. W niniejszym artykule przedstawiono założenia do przedmiotowego projektu, ze szczególnym uwzględnieniem roli i miejsca Narodowego Instytutu Onkologii i Hematologii.

\section{Przykłady amerykańskie}

Narodowy Instytut Nowotworów ( $\mathrm{NCl}$, National Cancer Institute) w USA, mieszczący się w Bethesdzie, jest jedną z najważniejszych instytucji na świecie dedykowanych walce z nowotworami. Został utworzony w 1937 roku i obecnie jest częścią Narodowego Instytutu Zdrowia (NIH, National Institute of Health). Narodowy Instytut Nowotworów w USA koordynuje Narodowy Program Zwalczania Chorób Nowotworowych, prowadzi i wspiera finansowo badania naukowe, organizuje szkolenia, rozpowszechnia wiedzę na temat onkologii oraz odpowiada za rozwój diagnostyki, profilaktyki i terapii w onkologii. Szczegółowe cele NCl obejmują: koordynację projektów badawczych prowadzonych przez uniwersytety oraz szpitale i fundacje naukowe, udzielanie grantów badawczych, prowadzenie akcji edukacyjnej i szkoleń w zakresie nauk podstawowych oraz dyscyplin klinicznych, obsługę krajowej sieci ośrodków onkologicznych, współpracę z organizacjami paramedycznymi i fundacjami oraz innymi krajowymi i zagranicznymi instytucjami zajmującymi się chorobami nowotworowymi.

W USA utworzono ponadto sieć onkologiczną składającą się z 21 wiodących amerykańskich centrów onkologicznych (NCCN, National Comprehensive Cancer Network), która opracowuje między innymi zalecenia i wytyczne diagnostyczno-lecznicze dla wszystkich nowotworów, z uwzględnieniem typu i zaawansowania, które są zamieszczane na stronie internetowej lub bezpłatnie przesyłane w formie papierowej do zainteresowanych osób i instytucji. Poza tym NCCN organizuje liczne konferencje i szkolenia, a także finansuje stypendia i projekty badawcze. Ośrodki onkologiczne, które tworzą NCCN, są wielospecjalistycznymi centrami medycznymi o typie CCC. Wszystkie mają zbliżoną strukturę i cele działania [5]. Należą do nich między innymi: Memorial Sloan Kettering Cancer Centre, Dana-Farber Massachusetts General Hospital Cancer Center, Robert H. Lurie Comprehensive Cancer Center of Northwestern University, Duke Cancer Institute, University of Michigan Comprehensive Cancer Center, Stanford Cancer Institute, Roswell Park Cancer Institute, City of Hope Comprehensive Cancer Center i St. Jude Children's Research Hospital/University of Tennessee Cancer Institute.

\section{Przykłady europejskie}

W Holandii, gdzie rocznie notuje się około 90000 nowych zachorowań na nowotwory, opieka onkologiczna jest koordynowana przez Holenderski Instytut Chorób Nowotworowych (NKI-AVL, The Netherlands Cancer Institute - A. van Leeuwenhoek Hospital), utworzony w 1916 roku. W NKI-AVL jest zatrudnionych 53 lekarzy specjalistów i 550 pracowników nauki, znajduje się 180 łóżek szpitalnych, 5 sal operacyjnych i 9 stanowisk radioterapii. W ambulatorium NKI-AVL rocznie jest przyjmowanych 24000 nowych chorych. Poza tym 
NKI-AVL pełni ważną rolę krajowego i międzynarodowego centrum diagnostyczno-leczniczego, zajmuje się badaniami naukowymi oraz szkoleniem nowych kadr. W NKI-AVL ściśle współpracują naukowcy i klinicyści, co umożliwia prowadzenie badań translacyjnych [6].

W styczniu 2011 roku utworzono Kompleksowe Centrum Onkologiczne (IKNL, Integraal Kankercentrum Nederland), które skupia 7 wielospecjalistycznych ośrodków onkologicznych zlokalizowanych w Holandii. Głównymi zadaniami IKNL są: zmniejszenie liczby zachorowań na nowotwory, poprawa wyników leczenia i jakości opieki nad chorymi oraz prowadzenie badań naukowych w dziedzinie onkologii. Kompleksowe Centrum Onkologiczne zapewnia chorym na nowotwory i ich rodzinom dostęp do wysokospecjalistycznej i kompleksowej opieki medycznej oraz opieki paramedycznej, psychospołecznej i pielęgniarskiej prowadzonej możliwie najbliżej miejsca zamieszkania. Inne zadania IKNL to: prowadzenie rejestru nowotworów i opracowywanie raportów epidemiologicznych, opracowywanie wytycznych i rekomendacji onkologicznych obejmujących cały zakres opieki onkologicznej — od zapobiegania i kontroli, poprzez diagnostykę, do leczenia przyczynowego i wspomagającego. Centrum koordynuje również opiekę paliatywną, organizację hospicjów stacjonarnych i domowych, rehabilitację chorych na nowotwory oraz Narodowy Program Kontroli Chorób Nowotworowych. Do zadań IKNL należy również koordynacja konsultacyjnej sieci ekspertów. Sieć ta skupia liderów z poszczególnych specjalności, w tym chirurgii i radioterapii onkologicznej, onkologii i hematologii oraz patomorfologii. Konsultanci IKNL są zobowiązani do wydawania opinii na temat trudnych diagnostycznie i terapeutycznie sytuacji klinicznych, co ułatwia stosowanie optymalnego leczenia również poza nim (np. szpital znajdujący się w pobliżu miejsca zamieszkania). Ujednolicenie sposobu postępowania w danej sytuacji klinicznej oraz przestrzeganie rekomendacji stało się kluczowe dla poprawy jakości opieki nad chorymi na nowotwory [7].

Holenderski IKNL odpowiada również za edukację społeczeństwa i kadr medycznych oraz prowadzenie prac naukowo-badawczych z dziedziny onkologii. Organizuje szkolenia, konferencje, spotkania tematyczne dla pracowników ochrony zdrowia i społeczeństwa, a także koordynuje wieloośrodkową i międzynarodową współpracę naukową oraz jest odpowiedzialne za prowadzenie banku tkanek. Kompleksowe Centrum Onkologiczne jest finansowane z funduszy państwowych (Ministerstwo Zdrowia, Opieki Społecznej i Sportu) oraz z grantów naukowo-badawczych i darowizn fundacji lub Holenderskiego Towarzystwa Onkologicznego. Działania NKI-AVL oraz IKNL w Holandii obecnie uznaje się za jedno z wiodących na świecie pod względem opieki onkologicznej oraz postępu wiedzy w walce $z$ nowotworami.

W innych krajach UE również powołano narodowe instytuty nowotworów - ich cele, zasady działania i wymierne efekty są zbliżone do przedstawionego modelu opieki on- kologicznej zorganizowanej w Holandii. Do wspomnianych instytucji europejskich należą L'Institut National du Cancer (INCA) i L'institut de Cancérologie Gustave Roussy (ICGR) we Francji oraz Istituto Nazionale dei Tumori di Milano (INTM) we Włoszech [8-10].

\section{Polska - stan obecny}

Obecnie w Polsce istnieje trójstopniowy model opieki onkologicznej, w tym powiatowe i dzielnicowe poradnie onkologiczne (I stopień), monoterapeutyczne oddziały szpitalne o profilu onkologicznym wraz z podstawowym zapleczem diagnostycznym i częścią ambulatoryjną (II stopień) oraz wielospecjalistyczne regionalne i akademickie ośrodki onkologiczne i hematologiczne wraz z CO-I w Warszawie i oddziałami w Gliwicach i Krakowie oraz Instytutem Hematologii i Transfuzjologii (IHT), reprezentujące III stopień referencyjności.„,Obowiązujący”w Polsce stopień referencyjności świadczeniodawców jest uznaniowy, a nie certyfikowany, a jakość udzielanych w nich świadczeń - deklarowana, a nie audytowana. Opracowany na wniosek ministra zdrowia, przez konsultanta krajowego ds. onkologii i ekspertów z CO-I w 2012 roku, algorytm certyfikacji poziomów referencyjności w oparciu o potencjał wykonawczy świadczeniodawcy, w tym liczbę i kwalifikacje personelu medycznego, wyposażenie w sprzęt i aparaturę medyczną oraz możliwości diagnostyczno-terapeutyczne, nie został - jak dotąd - wykorzystany przez Narodowy Fundusz Zdrowia (NFZ) w rankingowaniu ośrodków przystępujących do umowy na realizację świadczeń onkologicznych.

Mimo wysokiej jakości i kompleksowości świadczeń onkologicznych realizowanych przez jednostki o najwyższym stopniu referencyjności istnieją jeszcze liczne ograniczenia i obszary wymagające poprawy. Nie do zaakceptowania są nierównomierny dostęp do skojarzonych (wielodyscyplinarnych) świadczeń diagnostyczno-terapeutycznych oraz niewystarczająca skuteczność i bezpieczeństwo leczonych chorych na nowotwory. Na taką sytuację wpływa między innymi nieprzestrzeganie przez świadczeniodawców wytycznych diagnostyczno-leczniczych, czyli dowolność postępowania diagnostycznego i leczniczego w onkologii, w tym nieuzasadnione różnice $w$ takim postępowaniu w przypadku identycznych problemów zdrowotnych. Świadczą o tym między innymi wyniki interwencyjnych audytów konsultantów krajowych i wojewódzkich oraz wyniki kontroli przeprowadzonych przez NFZ.

Dużym problemem pozostaje rozproszenie realizacji świadczeń onkologicznych i kadry medycznej poprzez nieprzemyślane inwestycje w powstawanie nowych podmiotów - publicznych i niepublicznych - w oderwaniu od rzeczywistych potrzeb epidemiologicznych i już istniejących świadczeniodawców w danym regionie. Komercjalizacja niesie za sobą preferencję do wykonywania świadczeń przynoszących korzyści ekonomiczne. Świadczą o tym między 
innymi obserwowane od kilku lat wzrosty w kontraktowaniu świadczeń i procedur korzystnie wycenianych przez NFZ — niemających uzasadnienia we wskaźnikach zachorowalności. Część podmiotów decyduje się wykonywać jedynie opłacalne procedury, uszczuplając w ten sposób środki na podstawowe i najpotrzebniejsze świadczenia onkologiczne (o najlepszym stosunku koszt-efekt).

Ponadto kontraktowanie świadczeń onkologicznych z NFZ nie uwzględnia kompleksowości diagnostyki i leczenia jako czynnika rankingującego ośrodki. To oczywiste, że kompleksowa diagnostyka i leczenie nowotworu w wielospecjalistycznym ośrodku onkologicznym kosztuje więcej niż realizacja „kontraktu onkologicznego" w ramach terapii jednodniowej lub wybranych procedur radioterapeutycznych w wąskoprofilowym zakładzie opieki zdrowotnej (ZOZ). Jednostki wielospecjalistyczne muszą między innymi utrzymywać odpowiednią aparaturę, zatrudniać specjalistów z wielu dziedzin medycyny, zapewnić 24-dodzinny dostęp do izby przyjęć i oddziałów anestezjologii i intensywnej terapii oraz zapewnić pełny zakres specjalistycznych linii dyżurowych. W imię równego uprawnienia dostępu do realizacji świadczeń medycznych opłacanych przez NFZ kontrakt w danej dziedzinie jest rozdrabniany na małe jednostki, a w konkursie i wycenie punktu nie są brane pod uwagę wartości kompleksowego leczenia. Pomijając brak w tej sytuacji optymalnego planowania i realizacji sekwencyjnej, wielodyscyplinarnej strategii leczniczej dla indywidualnego pacjenta z chorobą nowotworową, liberalizm ten powoduje dalsze rozpraszanie niewystarczających funduszy na opłacenie ich działalności i rozpraszanie kadry medycznej.

Dysponując tak nieliczną kadrą onkologów i hematologów, radioterapeutów i fizyków medycznych, chirurgów onkologicznych i pielęgniarek onkologicznych, nie mamy żadnej sensownej polityki limitowania liczby podmiotów udzielających świadczenia onkologiczne oraz rodzaju i liczby kontraktowanych w nich świadczeń. Wolny rynek świadczeń medycznych zamiast poprawiać jakość opieki zdrowotnej, powoduje pogarszanie sytuacji finansowej dużych wielospecjalistycznych podmiotów leczniczych oraz nasila trudności związane z obowiązkowym standardem zatrudnienia we wszystkich placówkach. Tworzy się rynek niedoboru specjalistów i w efekcie stawki godzinowe za ich pracę stale rosną. To pogłębia problemy finansowe dużych, wielospecjalistycznych publicznych placówek, w przeciwieństwie do "wąsko” wyspecjalizowanych ZOZ-ów — realizujących w przeważającym zakresie dobrze wycenione świadczenia medyczne, na dodatek jedynie do limitu posiadanego kontraktu (bez nadwykonań).

Utrwala się też błędny obraz rzeczywistości, w którym niewielkie - monoterapeutyczne - ośrodki działają na zdrowszych i efektywniejszych zasadach, a wielospecjalistyczne centra onkologii, w tym instytuty, wydają się relik- tem poprzedniej epoki. Prawda jest jednak taka, że wszystkie te działania, a zwłaszcza rosnąca bez żadnej kontroli liczba podmiotów walczących ze sobą w imię„,konkurencji” o wyrwanie swojej części od publicznego płatnika, drenują system z pieniędzy i specjalistów - nie tylko nie przynosząc społeczeństwu oczekiwanych korzyści zdrowotnych, ale pogarszając dostęp pacjenta z chorobą nowotworową do skojarzonych, wielodyscyplinarnych świadczeń diagnostyczno-leczniczych.

\section{Polska - projekt zmian}

Rynek świadczeń onkologicznych nigdy nie był i nie powinien być rynkiem wolnym — „ doskonale"konkurencyjnym. Doświadczenia krajów wysoko uprzemysłowionych wskazują, że powinien być rynkiem regulowanym, wyposażonym w odpowiednie mechanizmy i narzędzia regulacji, których w polskiej onkologii zdecydowanie brakuje. Najważniejszym celem na dziś jest zapewnienie — w ramach ograniczonych środków - poprawy dostępności, jakości, skuteczności oraz bezpieczeństwa skojarzonych świadczeń diagnostyczno-leczniczych, w pierwszej kolejności tych najbardziej skutecznych, o najlepszym stosunku kosztu do uzyskiwanego efektu. Dobry, równy i sprawiedliwy dostęp do nich może być zapewniony nie tyle na drodze tworzenia nowych podmiotów, ile dzięki lepszej i bardziej efektywnej współpracy między już istniejącymi ośrodkami onkologicznymi i hematologicznymi oraz innymi szpitalami, ambulatoryjną opieką specjalistyczną i podstawową opieką zdrowotną - w tym na zasadach partnerstwa publiczno-prywatnego.

Spośród mechanizmów i narzędzi regulacyjnych najważniejsze dotyczą zarządzania zawartością koszyka świadczeń gwarantowanych oraz wyceną i zasadami finansowania i rozliczania świadczeń onkologicznych. Poza oczywistą rolą w tym względzie Agencji Oceny Technologii Medycznych (AOTM) i Agencji Taryfikacji konieczne będzie zbudowanie systemu zapewnienia jakości, gdyż w onkologii i hematologii często poruszamy się na granicy interwencji szkodliwych, pogarszających jakość życia, a nawet skracających życie pacjentów z chorobą nowotworową.

W pierwszej kolejności należy zacząć od przeprowadzenia inwentaryzacji już posiadanej kadry specjalistycznej, infrastruktury, aparatury i sprzętu oraz lokalizacji podmiotów udzielających świadczeń z zakresu onkologii, hematologii, radioterapii i chirurgii onkologicznej. Następnie trzeba porównać ten potencjał wykonawczy z mapą rzeczywistych potrzeb zdrowotnych w wyżej wymienionych zakresach. $\mathrm{Na}$ tej podstawie będzie można zdefiniować obszary i zakresy wymagające inwestycji oraz niewymagające takich działań. W związku z projektem rozporządzenia dotyczącego udzielania świadczeń zdrowotnych i propozycją uwzględnienia kompleksowości jako czynnika rankingującego ośrodki przystępujące do umowy na realizację świadczeń z publicznym płatnikiem niezbędne będzie także zdefiniowa- 
nie parametrów certyfikatu kompetencji — stanowiącego podstawę określenia poziomu referencyjności dla każdego świadczeniodawcy. Konieczne będzie opracowanie zasad finansowania i rozliczania świadczeń onkologicznych zależnie od posiadanego stopnia referencyjności oraz monitorowania jakości udzielanych świadczeń. Trzeba będzie dążyć do standaryzacji procedur diagnostyczno-leczniczych dotyczących wszystkich nowotworów, z uwzględnieniem ich typu i zaawansowania, a także do zapewnienia każdemu pacjentowi dostępu do wielospecjalistycznego leczenia sekwencyjnego - zarówno na etapie jego planowania, jak i realizacji, na podstawie indywidualnego planu leczenia opracowanego przez zespół specjalistów w ramach MDT.

Tworzony system powinien być zinstytucjonalizowany w taki sposób, aby w miarę pojawiania się nowych wyzwań i priorytetów pozwolił na jego płynne zmiany i adaptację w przyszłości, w tym skuteczną i wydajną drogę odwoławczą. Wszystkie działania powinny zmierzać do spełnienia podstawowego celu, jakim jest poprawa skuteczności i bezpieczeństwa opieki onkologicznej realizowanej ze środków publicznych, poprzez stworzenie sieci współpracujących ze sobą placówek, dla których czynnikiem pozycjonującym nie będzie organ tworzący czy struktura właścicielska, a jedynie faktycznie posiadany potencjał wykonawczy mierzony certyfikatami kompetencji, poziomem referencyjności, wystandaryzowanymi procedurami diagnostyczno-leczniczymi, MDT opracowującymi indywidualne plany leczenia oraz wewnętrznymi i zewnętrznymi systemami monitorowania jakości udzielanych świadczeń. Ponadto w planowanych zmianach trzeba będzie uwzględnić rozwiązania systemowe poprawiające koordynację i realizację specjalistycznego kształcenia podyplomowego.

Sprawdzony w krajach wysoko uprzemysłowionych model systemu opieki onkologicznej oparty na sieci onkologicznej wielospecjalistycznych centrów skupionych wokół jednostki koordynującej powinien stanowić wzór dla utworzenia podobnego systemu w Polsce. Na szczęście, nie musimy tworzyć go od podstaw, a jedynie uporządkować istniejący stan rzeczy.

Podległe centralnym organom administracji rządowej instytuty zajmujące się od kilkudziesięciu lat problematyką chorób nowotworowych - CO-I w zakresie nowotworów narządów litych oraz IHT w zakresie nowotworów hematologicznych - mają podobną strukturę i cele, jak narodowe instytuty nowotworów w USA oraz w krajach UE. Sieć onkologiczna - utworzona na bazie instytutów oraz uniwersyteckich i regionalnych WCO - może być podobna do IKNL w Holandii czy NCCN w USA. Do jej zadań należałoby między innymi koordynowanie konsultacyjnej sieci specjalistów w zakresie onkologii, hematologii i onkohematologii dziecięcej, chirurgii i radioterapii onkologicznej, transplantologii i transfuzjologii, patomorfologii i psychoonkologii oraz diagnostyki radiologicznej i laboratoryjnej, co ułatwiałoby kompleksową diagnostykę i stosowanie optymalnego leczenia, a także ujednolicenie i przestrzeganie rekomendacji w tym zakresie — nie tylko w ramach sieci, ale także poza jednostkami o najwyższym poziomie referencyjności.

Nadrzędnym celem działalności sieci onkologicznej byłoby ujednolicenie i standaryzacja wielospecjalistycznych świadczeń diagnostycznych i skojarzonej terapii chorych na nowotwory, z dostosowaniem ich do wymogów europejskich i dyrektywy EURATOM 97/43, a także stworzenie platformy do koordynacji i wymiany doświadczeń wraz z krajową siecią teleonkologii. Oczekiwaną i realną konsekwencją tych działań będzie zwiększenie dostępu chorych do wielospecjalistycznych świadczeń onkologicznych, skrócenie oczekiwania na leczenie i skrócenie czasu leczenia skojarzonego.

\section{Rola CO-I oraz IHT w systemie opieki onkologicznej}

Oba instytuty badawcze - CO-I oraz IHT — spełniają wymogi światowe dotyczące świadczenia opieki zdrowotnej i są wiodącymi w Polsce ośrodkami onkologicznymi i hematologicznymi prowadzącymi działalność leczniczą, naukową i edukacyjną [11, 12]. W obu instytutach istnieje możliwość optymalnej kooperacji między klinicystami i przedstawicielami nauk podstawowych. Struktura organizacyjna obu instytutów jest zgodna z ogólnymi tendencjami światowymi, czyli składa się z części klinicznej i naukowo-badawczej.

Część kliniczna jest podzielona na tak zwane kliniki narządowe (cancer units) zajmujące się kompleksowo określonymi nowotworami, w tym głowy i szyi, płuca, piersi, przewodu pokarmowego, urologicznymi, ginekologicznymi, endokrynologicznymi, neurologicznymi, kości i tkanek miękkich oraz układu chłonnego i krwiotwórczego. W uzupełnieniu działalności zachowawczej (chemioterapii, radioterapii, hematologii, interny, anestezjologii i intensywnej terapii, medycyny paliatywnej, rehabilitacji i psychonkologii) oraz operacyjnej (chirurgia onkologiczna, ogólna i naczyniowa) w obu instytutach jest realizowany program przeszczepiania krwiotwórczych komórek macierzystych (auto- i allogenicznego), a odpowiednie kliniki posiadają akredytacje Ministerstwa Zdrowia oraz European Group for Blood and Marrow Stem Cell Transplantation (EBMT) na wykonywanie wszystkich rodzajów transplantacji. Ponadto jest ośrodek dawców szpiku, który współpracuje w tym zakresie z Krajowym Rejestrem Dawców Szpiku i Poltransplantem. Zakłady Teleradioterapii oraz Brachyterapii realizują wszystkie współcześnie dostępne procedury leczenia promieniami — radioterapię z modulowaną intensywnością wiązki, radioterapię konformalną (3D), jednoczesną i sekwencyjną radiochemioterapię, napromienianie kojarzone z lekami ukierunkowanymi molekularnie oraz chemioterapią i wszystkie procedury napromieniania w brachyterapii. Zakłady diagnostyczne świadczą pełen zakres usług cytologicznych, cytochemicznych, immunofenotypowych, patomorfologicznych, immunohistochemicznych i genetycznych oraz w zakresie radiologicznych technik 
Tabela I. Kadra specjalistyczna i naukowa Centrum Onkologii — Instytutu im. Marii Skłodowskiej-Curie i Instytutu Hematologii i Transfuzjologii w 2012 roku

\begin{tabular}{|c|c|c|c|c|}
\hline & \multicolumn{4}{|c|}{ Pracownicy naukowi } \\
\hline & \multicolumn{2}{|c|}{ Samodzielny pracownik naukowy } & \multicolumn{2}{|c|}{ Profesor zwyczajny } \\
\hline CO-I Warszawa & \multicolumn{2}{|c|}{35} & \multicolumn{2}{|c|}{19} \\
\hline CO-I Gliwice & \multicolumn{2}{|c|}{22} & \multicolumn{2}{|c|}{11} \\
\hline CO-I Kraków & \multicolumn{2}{|c|}{21} & \multicolumn{2}{|c|}{12} \\
\hline IHT & \multicolumn{2}{|c|}{16} & \multicolumn{2}{|c|}{7} \\
\hline \multirow[t]{3}{*}{ Łącznie } & \multicolumn{2}{|c|}{94} & \multicolumn{2}{|c|}{49} \\
\hline & \multicolumn{4}{|c|}{ Specjaliści } \\
\hline & Warszawa & Gliwice & Kraków & Łącznie \\
\hline Onkologia kliniczna & 66 & 14 & 12 & 92 \\
\hline Chirurgia onkologiczna & 35 & 12 & 10 & 57 \\
\hline Radioterapia onkologiczna & 51 & 51 & 28 & 133 \\
\hline Hematologia & 30 & 4 & 3 & 37 \\
\hline
\end{tabular}

CO-I — Centrum Onkologii — Instytut im. Marii Skłodowskiej-Curie; IHT — Instytut Hematologii i Transfuzjologii; NFZ — Narodowy Fundusz Zdrowia

obrazowania. Dzięki takzorganizowanej strukturze opieka onkologiczna w obu instytutach jest prowadzona kompleksowo, a kadra medyczna ma odpowiednie doświadczenie kliniczne w diagnostyce i leczeniu poszczególnych nowotworów (tab. I).

Oba instytuty były i są głównymi ośrodkami w Polsce prowadzącym szkolenia kadr medycznych w onkologii i hematologii. Na terenie IHT działa Klinika Hematologii i Transfuzjologii Centrum Medycznego Kształcenia Podyplomowego (CMKP). W nowym roku akademickim planowane jest otwarcie Kliniki Radioterapii Onkologicznej CMKP w oddziale CO-I w Gliwicach, a następnie Kliniki Onkologii CMKP w CO-I (Warszawa). Obecna działalność edukacyjna polega na organizowaniu kursów doskonalących dla lekarzy odbywających specjalizację z onkologii klinicznej, hematologii i transfuzjologii oraz chirurgii onkologicznej, radioterapii onkologicznej, ginekologii onkologicznej, a także anestezjologii i medycyny paliatywnej. Inną formą działalności dydaktycznej są kursy i szkolenia, podczas których w kompleksowy sposób są omawiane nowotwory poszczególnych narządów. Oba instytuty posiadają także własne wydawnictwa - periodyki edukacyjne wydawane samodzielnie („Hematologia” $i$,Journal of Transfusion Medicine") lub w powiązaniu z odpowiednimi towarzystwami naukowymi: „Acta Haematologica Polonica” z Polskim Towarzystwem Hematologów i Transfuzjologów (PTHiT) oraz "Nowotwory" z Polskim Towarzystwem Onkologicznym (PTO). Pracownicy obu instytutów biorą aktywny udział w przygotowaniu i wydawaniu „Zaleceń postępowania diagnostyczno-terapeutycznego w nowotworach złośliwych" oraz "Medycznych zasad pobierania krwi, oddzielania jej składników i wydawania obowiązujących w jednostkach organizacyjnych publicznej służby krwi".

Większość badań naukowych jest prowadzona przez kliniki CO-I oraz IHT w ścisłej współpracy z zakładami badań podstawowych i translacyjnych oraz z innymi jednostkami naukowo-badawczymi w kraju i za granica, w tym w ramach wieloośrodkowych badań klinicznych. Oba instytuty podpisały między innymi umowę konsorcyjną w zakresie prowadzenia wspólnych projektów naukowych zMDAnderson CancerCenter wUSA, przede wszystkim służące rozszerzaniu wiedzy na temat biologii nowotworów w kontekście rozwoju przyszłych metod diagnostycznych i terapeutycznych. Ponadto CO-I jest od wielu lat wiodącym ośrodkiem w badaniach zzakresu epidemiologii nowotworów i pełni funkcję ośrodka współpracującego ze Światową Organizacją Zdrowia (WHO, World Health Organization) w dziedzinie planowania i wdrażania działań WHO na rzecz Europy wolnej od tytoniu (WHO Collaborating Centre for Action Plan for Tobacco-free Europe), którego głównym celem jest zmniejszenie zagrożenia zdrowia w związku z paleniem tytoniu w Polsce i innych krajach Europy Środkowo-Wschodniej. Prowadzi stałą współpracę naukowo-badawczą z International Agency for Research on Cancer w Lyonie, NCl i Centerfor Diseases Control and Prevention w Atlancie oraz Uniwersytetem w Oksfordzie.

Centrum Onkologii — Instytut jest również odpowiedzialne za prowadzenie Krajowego Rejestru Nowotworów Złośliwych oraz koordynuje w tym zakresie działalność rejestrów wojewódzkich. Od czasu powołania Narodowego Programu Zwalczania Chorób Nowotworowych, Zakład Epidemiologii CO-I koordynuje program Prewencji Pierwotnej Nowotworów. Dojego zadań należą: prowadzenie działalności edukacyjnej i informacyjnej, upowszechnianie Europejskiego Kodeksu Walkiz Rakiem, koordynacja regionalnych programów szkoleniowo-edukacyjnych w zakresie prewencji pierwotnej przez regionalne WCO. W 2011 roku otwarto Centrum Profilaktyki Nowotworów, które jest pierwszą placówką w Polsce umożliwiającą prowadzenie kompleksowej profilaktyki raka piersi, raka szyjki macicy, nowotworów skóry, raka jelita grubego, badań skłonności genetycznych do występowania nowotworów oraz prewencji pierwotnej raka płuca w ramach Poradni Pomocy 
Palącym, oferującej leczenie zespołu uzależnienia od tytoniu, w tym farmakoterapię i psychoterapię. W ramach Zakładu Epidemiologii i Prewencji Nowotworów prowadzona jest także ogólnopolska Telefoniczna Poradnia Pomocy Palącym, która oferuje profesjonalne porady wyszkolonych terapeutów osobom zmagającym sięz problemem palenia tytoniu, ich rodzinom ibliskim oraz wszystkim poszukującym informacji na temat sposobów zminimalizowania ryzyka zachorowania na nowotwór.

\section{Inicjatywa utworzenia Narodowego Instytutu Onkologii i Hematologii}

Pierwsze rządowe plany połączenia Instytutu Onkologii z Instytutem Hematologii miały miejsce w latach 70. XX wie-ku, gdy pod tytułem budowy nowych siedzib dla obu instytutów na Ursynowie uzyskano wspólną decyzję lokalizacyjną nr 59/74 z dnia 15.02.1974 roku. Wspólna działka, zgodnie z programem funkcjonalnym inwestycji, miała pozwolić na zmniejszenie kosztów poprzez budowę wspólnego zaplecza infrastruktury pomocniczej. Budowa miała mieć charakter dwuetapowy; w pierwszej kolejności zdecydowano o budowie Instytutu Onkologii wraz ze wspólnym zapleczem dla obu instytutów, a w drugiej - budowę Instytutu Hematologii.

Niestety, ze względów finansowych rozpoczęcie 2. etapu inwestycji odsunięto w czasie na kolejne 25 lat, co przekreśliło możliwość funkcjonalnego połączenia obu instytutów. Połączeniu nie sprzyjały także trudne relacje dwóch wybitnych osobowości - dyrektorów instytutów - z tego okresu: profesora Tadeusza Koszarowskiego (dyrektora Instytutu Onkologii w latach 1972-1985) i profesora Witolda Rudowskiego (dyrektora Instytutu Hematologii w latach 1964-1988). Należy przypomnieć, że profesor Witold Rudowski rozpoczął pracę w Instytucie Radowym w 1943 roku - jeszcze w okresie tajnych studiów medycznych, a następnie w Klinice Chirurgii Onkologicznej Instytutu Onkologii przy ul. Wawelskiej (lata 1948-1964), kierowanej przez profesora Tadeusz Koszarowskiego. Przez wiele lat pełnił także funkcję sekretarza naukowego Instytutu Onkologii, a przez 18 lat (1956-1974) — funkcję redaktora naczelnego czasopisma "Nowotwory", organu PTO i Instytutu Onkologii. Z nieznanych przyczyn Ich bardzo bliska i twórcza współpraca na początku pracy zawodowej nie doczekała się kontynuacji w późniejszych latach [13, 14].

Temat połączenia obu Instytutów powrócił po 25 latach, gdy w 1997 roku rozpoczęto na Ursynowie budowę nowej siedziby Instytutu Hematologii. Minister zdrowia, decyzją z 10 marca 1997 roku, przydzielił pierwszą transzę środków na budowę, którą wykorzystano do 2000 roku na wykonanie projektu budowlanego i wybudowanie fundamentów budynku klinicznego.W tym samym roku przekazano z budżetu państwa kolejną transzę środków, zmniejszając jednak ogólne koszty inwestycji do 80 mln złotych, z zakładanych wcześniej $300 \mathrm{mln}$ złotych, co ponownie uniemożliwiło wybudowanie wspólnej dla obu Instytutów infrastruktury szpitalnej. Przeszkód stojących na drodze do połączenia instytutów było w tym czasie wiele. Brakowało między innymi przepisów wykonawczych umożliwiających konsolidację instytutów w ustawie o jednostkach badawczo-rozwojowych. W opracowaniu była także nowelizacja ustawy o publicznej służbie krwi, która — zgodnie z dyrektywą akcesyjną UE — wymagała pilnego wytypowania instytucji pełniącej nadzór merytoryczny nad jednostkami organizacyjnymi publicznej służby krwi w Polsce. Ze względów merytorycznych i historycznych instytucją wskazywaną do tej roli był IHT, który zobowiązano między innymi do przejęcia metodycznych, prawnych i organizacyjnych zadań likwidowanego Krajowego Centrum Krwiodawstwa i Krwiolecznictwa. Do przeszkód legislacyjnych łączenia obu instytutów dołączyły inne problemy, w tym nieuregulowany stan prawny własności terenów, na których — zgodnie z decyzją wywłaszczeniową i lokalizacyjną nr 59/74 z dnia 15.02.1974 roku — posadowiono nowe instytuty. Trudny do oszacowania był termin zakończenia budowy nowej siedziby IHT na Ursynowie realizowanej w imieniu Ministerstwa Zdrowia przez inwestora zastępczego, jakim był Zarząd Inwestycji Centralnych. Dla przykładu, budowa Instytutu Onkologii na podstawie tej samej decyzji inwestycyjnej trwała przeszło 20 lat zamiast planowanych 6. Nie do pogodzenia były też zupełnie różne procedury zarządzania oboma instytutami, których skrajnym przejawem była dobra od lat sytuacja finansowa IHT i katastrofalny stan finansów po stronie CO-I. Należy pamiętać również o tym, że organem założycielskim niemal $100 \%$ szpitali w Polsce na początku lat 2000 były organy publicznej władzy samorządowej lub centralnej i nie planowano w tym zakresie żadnych przekształceń własnościowych ani reorganizacyjnych.

W 2013 roku sytuacja w wyżej wymienionych obszarach jest zupełnie różna. Z jednej strony, przekształcenia własnościowe w służbie zdrowia objęły ponad $40 \%$ szpitali i dynamika tego procesu narasta w czasie. Do strategicznych planów Ministerstwa Zdrowia należą między innymi reorganizacje szpitali klinicznych i instytutów resortowych, w tym przekształcenia w spółki prawa handlowego, a w skrajnych przypadkach — likwidacje.Z drugiej strony, ustawa o jednostkach badawczych z 30 kwietnia 2010 roku stała się instrumentem prawnym sprzyjającym konsolidacji sektora badawczego. Rada Ministrów, z inicjatywy ministra właściwego do spraw zdrowia, może w drodze łączenia instytutów tworzyć Państwowe Instytuty Badawcze (PIB) jako jednostki o znaczącym potencjale kadrowym i aparaturowym, zdolne prowadzić interdyscyplinarne badania naukowe, a jednocześnie wypełniać ważne z punktu widzenia interesu społecznego zadania państwowe.

W opinii Rad Naukowych IHT i CO-I, pracowników obu instytutów i większości działających w nich organizacji związków zawodowych, a także przedstawicieli zarządów onkologicznych towarzystw naukowych (PTOK, PTCHO, 
Tabela II. Przychody Centrum Onkologii — Instytutu im. Marii Skłodowskiej-Curie i Instytutu Hematologii i Transfuzjologii w 2012 roku, w tym z tytułu realizacji kontraktów z Narodowym Funduszem Zdrowia

\begin{tabular}{lccc}
\hline & \multicolumn{2}{c}{ Kontrakty z NFZ w 2012 r. [mln PLN] } & Przychody w 2012 r. [mln PLN] \\
\cline { 2 - 4 } & Bez nadwykonań & Z nadwykonaniami & Łącznie \\
\hline CO-I Warszawa & 367,28 & 380,00 & 454,27 \\
CO-I Gliwice & 250,42 & 259,53 & 300,77 \\
CO-I Kraków & 85,40 & 91,09 & 187,08 \\
IHT & 115,35 & 120,81 & 199,13 \\
Łącznie & 818,45 & 851,423 & $\mathbf{1} \mathbf{~ m l d ~ 1 4 1 , 2 5} \mathbf{~ m l n}$ \\
\hline
\end{tabular}

CO-I — Centrum Onkologii — Instytut im. Marii Skłodowskiej-Curie; IHT — Instytut Hematologii i Transfuzjologii; NFZ — Narodowy Fundusz Zdrowia

Tabela III. Przykładowe zadania Narodowego Instytutu Onkologii i Hematologii oraz Krajowej Rady ds. Onkologii i Hematologii przy ministrze zdrowia

\begin{tabular}{|c|c|}
\hline $\begin{array}{l}\text { Narodowy Instytut Onkologii i Hematologii } \\
\text { opracowuje i aktualizuje }\end{array}$ & Zadania Krajowej Rady ds. Onkologii i Hematologii \\
\hline $\begin{array}{l}\text { - Wytyczne diagnostyczno-lecznicze dotyczące wszystkich } \\
\text { nowotworów, z uwzględnieniem typu i zaawansowania, } \\
\text { jako obowiązujące we wszystkich jednostkach realizujących } \\
\text { świadczenia onkologiczne ze środków publicznych } \\
\text { - Parametry certyfikatu kompetencji w zakresie liczby i rodzaju świad- } \\
\text { czeń onkologicznych i stopni referencyjności } \\
\text { - Programy szkoleniowe w zakresie specjalistycznego kształcenia } \\
\text { podyplomowego zlecanego przez CMKP } \\
\text { - Inicjatywy w zakresie modyfikacji katalogu świadczeń } \\
\text { gwarantowanych przez NFZ w zakresie profilaktyki i leczenia } \\
\text { nowotworów } \\
\text { - Projekty aktów prawnych w zakresie prewencji pierwotnej, prewencji } \\
\text { wtórnej, diagnostyki i leczenia nowotworów } \\
\text { - Prowadzenie Krajowego Rejestru Zachorowań na Nowotwory } \\
\text { - Raporty o częstości stosowania i skuteczności (przeżycia całkowite, } \\
\text { wyleczenie, powikłania) stosowanych metod diagnostyczno- } \\
\text {-terapeutycznych w ośrodkach realizujących świadczenia onkologiczne } \\
\text { ze środków publicznych wraz z oceną dostępności do ww. } \\
\text { w poszczególnych regionach i województwach w kraju }\end{array}$ & $\begin{array}{l}\text { - Zgłaszanie i opiniowanie propozycji do wytycznych } \\
\text { diagnostyczno-leczniczych, parametrów certyfikatu kompetencji } \\
\text { i stopni referencyjności dla jednostek realizujących świadczenia } \\
\text { onkologiczne ze środków publicznych, w tym opracowanych } \\
\text { przez NIOH i RDPWCO } \\
\text { - Przeprowadzanie audytów na wniosek jednostek realizują- } \\
\text { cych świadczenia onkologiczne w celu uzyskania certyfikatu } \\
\text { kompetencji i stopnia referencyjności } \\
\text { - Przeprowadzanie audytów następczych w jednostkach } \\
\text { realizujących świadczenia onkologiczne w celu aktualizacji } \\
\text { certyfikatu kompetencji i stopnia referencyjności } \\
\text { - Zgłaszanie i opiniowanie inicjatyw w zakresie modyfikacji } \\
\text { katalogu świadczeń gwarantowanych przez NFZ w zakresie } \\
\text { profilaktyki i leczenia nowotworów, w tym zgłaszanych przez } \\
\text { NIOH i RDPWCO } \\
\text { - Zgłaszanie i opiniowanie programów szkoleń w zakresie spe- } \\
\text { cjalistycznego kształcenia podyplomowego, w tym opracowanych } \\
\text { przez NIOH, RDPWCO i CMKP } \\
\text { - Zgłaszanie i opiniowanie projektów aktów prawnych } \\
\text { w zakresie prewencji pierwotnej, prewencji wtórnej, } \\
\text { diagnostyki i leczenia nowotworów, w tym opracowanych przez } \\
\text { NIOH i RDPWCO }\end{array}$ \\
\hline
\end{tabular}

$\mathrm{NIOH}$ — Narodowy Instytut Onkologii i Hematologii; CMKP — Centrum Medyczne Kształcenia Podyplomowego; NFZ — Narodowy Fundusz Zdrowia; RDPWCO — Rada Dyrektorów Publicznych Wielospecjalistycznych Centrów Onkologii

PTRO) i dyrektorów WCO, w tym liderów polskiej onkologii i hematologii (patrz Podziękowania), koordynowanie działań zmierzających do zapewnienia przez państwo właściwej opieki chorym na nowotwory, nadzoru merytorycznego nad publiczną służbą krwi oraz ciągłej edukacji kadr specjalistycznych decyduje o bezpieczeństwie zdrowotnym społeczeństwa, a tym samym przemawia za połączeniem CO-I z IHT w celu utworzenia instytutu o statusie PIB. W tym kontekście trudno jest czynić zarzut z faktu, że dyrektorem obu łączonych instytutów jest ta sama osoba [4]. Potencjał wykonawczy obu jednostek — mierzony liczbą i kwalifikacją personelu (tab. I), infrastrukturą i wyposażeniem w sprzęt i aparaturę medyczną, a także wielkością kontraktu z NFZ na realizację świadczeń onkologicznych (tab. II) — tym bardziej przekonuje do postawienia wspólnego celu strategicznego, jakim jest utworzenie Narodowego Instytutu ze statutowymi zadaniami rangi państwowej (tab. III).
Takie wnioski można było wyciągnąć między innymi na podstawie wielu dyskusji nt. projektu utworzenia Narodowego Instytutu podczas roboczych spotkań organizowanych z inicjatywy ministra zdrowia w pierwszej połowie 2012 roku, posiedzenia senackiej komisji zdrowia 11 grudnia 2012 roku, spotkań dyrekcji z pracownikami CO-I w Warszawie (5.02.2013 r. i 24.06.2013 r.), Krakowie (5.06.2013 r.) i Gliwicach (6.06.2013 r.) oraz podczas posiedzeń Rad Naukowych IHT iCO-I, odpowiednio, 10 czerwca i 12 czerwca tego roku. Projekt był omawiany podczas plenarnych spotkań organizowanych z inicjatywy Polskiej Unii Onkologii („Onkologia i hematologia 2013 r. Aspekty prawne i systemowe") w Warszawie (24.06.2013 r.), Polskiego Towarzystwa Onkologicznego (PTO) („Czas na onkologię — wspólna sprawa") w Gdańsku (28.06.2013 r.) oraz dyrektorówWCO w Bydgoszczy (23.07.2013 r.). Był także przedmiotem dyskusji nt. perspektywicznych planów rozwoju obu instytutów z udziałem przedstawicieli Ministerstwa Zdrowia, 


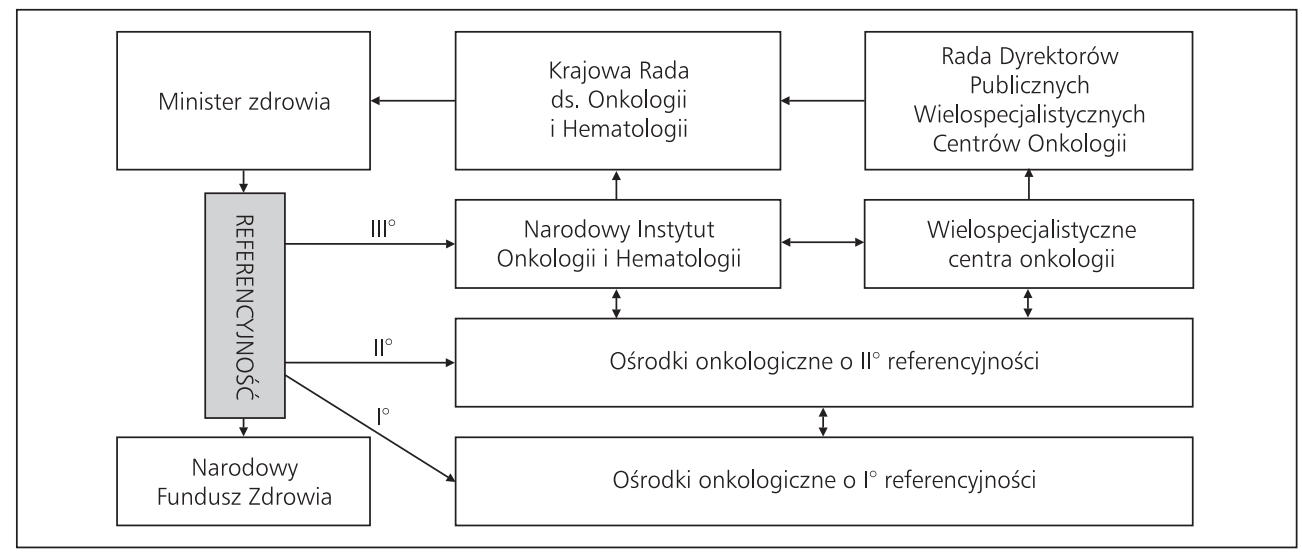

Rycina 1. Miejsca i rola wielospecjalistycznych centrów onkologii, Rady Dyrektorów Wielospecjalistycznych Publicznych Centrów Onkologii, Narodowego Instytutu Onkologii i Hematologii oraz Krajowej Rady ds. Onkologii i Hematologii w planowanej krajowej sieci onkologicznej

Ministerstwa Nauki i Szkolnictwa Wyższego oraz Komitetu Ewaluacji Jednostek Naukowych w trakcie procedur konkursowych na stanowiska dyrektora CO-I oraz IHT, odpowiednio, w styczniu 2012 roku i w kwietniu 2013 roku.

Uchwały Rad Naukowych wnioskujące o połączenie obu instytutów z utworzeniem Narodowego Instytutu Onkologii i Hematologii (NIOH) im. Marii Skłodowskiej-Curie z siedzibą w Warszawie o statusie PIB zostały podjęte w trakcie plenarnych posiedzeń 10 czerwca (IHT) i 12 czerwca tego roku (CO-I). 12 czerwca tego roku przedmiotowe uchwały wraz z identycznie brzmiącymi wnioskami dyrekcji obu instytutów, w tym oddziałów CO-I w Gliwicach i Krakowie, zostały złożone w Ministerstwie Zdrowia. Zgodnie z art. 8 ust. 3 ustawy z dnia 30 kwietnia 2010 roku o instytutach badawczych (Dz. U. nr 96, poz. 618, z późn. zm.) połączenie instytutów poprzedza postępowanie przygotowawcze mające na celu ocenę potrzeby oraz warunków ich połączenia. Minister nadzorujący jest zobowiązany do powołania zespołu roboczego do przeprowadzenia powyższego postępowania. Stosownie do regulacji zawartych w przepisach rozporządzenia Rady Ministrów z dnia 17 listopada 2010 roku w sprawie tworzenia, łączenia, podziału, reorganizacji, przekształcania, włączania lub likwidacji instytutów badawczych (Dz.U. nr 230, poz. 1512) dopiero po wydaniu przez wyżej wymieniony zespół opinii minister zdrowia powołuje komisję do oceny stanu majątkowego i organizacyjno-prawnego łączonych instytutów orazopracowania warunków, na jakich zostanie dokonane ich ewentualne połączenie.

Warto przy tej sposobności wspomnieć, że w ciągu minionego roku w obu instytutach doprowadzono do znaczącej harmonizacji procedur zarządczych oraz poprawy sytuacji finansowej, w tym do likwidacji ponad 100-milionowych zobowiązań (długu) CO-I.Wszystkie jednostki należące do obu instytutów mają płynność finansową oraz nie mają zobowiązań wymagalnych, a wysoki poziom majątku obrotowego powoduje, że wskaźnik płynności kształtuje się na w pełni zadowalającym poziomie. W 2012 roku łączny wynik finansowy IHT i CO-I był dodatni, z roku na rok w obu instytutach wzrastają przychody, w tym z tytułu kontraktów z NFZ, a dzięki realizowanym inwestycjom wartość majątku trwałego stale wzrasta.

\section{Propozycja zadań dla Narodowego Instytutu Onkologii i Hematologii}

Sprawdzony w krajach wysoko uprzemysłowionych model systemu opieki onkologicznej oparty na wielospecjalistycznych centrach skupionych wokół jednostki koordynującej-Narodowego Instytutu — powinien stanowić wzór dla zdefiniowania podobnych zadań dla WCO i NIOH w Polsce. Nadrzędnym celem działalności sieci onkologicznej byłoby ujednolicenie w kraju i standaryzacja wielospecjalistycznych świadczeń diagnostycznych i skojarzonej terapii oraz ułatwienie dostępu do nich chorym na nowotwory (ryc. 1).

Do statutowych zadań NIOH w zakresie onkologii, poza już istniejącymi zadaniami IHT w zakresie krwiodawstwa i krwiolecznictwa wynikającymi z zapisów ustawy o publicznej służbie krwi, należałoby opracowanie i aktualizacja: wytycznych diagnostyczno-leczniczych dla wszystkich nowotworów, parametrów certyfikatu kompetencji służących między innymi określaniu stopni referencyjności świadczeniodawców, programów szkoleniowych w zakresie specjalistycznego kształcenia podyplomowego, inicjatyw w zakresie modyfikacji katalogu świadczeń gwarantowanych przez NFZ, projektów aktów prawnych w zakresie prewencji pierwotnej, prewencji wtórnej, diagnostyki i leczenia nowotworów, prowadzenie Krajowego Rejestru Zachorowań na Nowotwory, raportów o częstości stosowania i skuteczności stosowanych metod diagnostyczno-terapeutycznych wraz z oceną dostępności do wyżej wymienionych w poszczególnych regionach i województwach w kraju (tab. III).

Ponadto NIOH mógłby realizować inicjatywy szkoleniowe dla personelu medycznego i społeczeństwa, opracowywać i monitorować wspólne inicjatywy podmiotów 
publicznych i prywatnych działających na rzecz prewencji, epidemiologii, badań przesiewowych, diagnostyki i leczenia oraz brać czynny udział w rozwoju inicjatyw europejskich i międzynarodowych, w tym inicjować badania naukowe związane z realizacją Narodowego Programu Zwalczania Chorób Nowotworowych. Powyższe działania mogłyby się przyczynić do poprawy ogólnej jakości opieki onkologicznej i postępu wiedzy w walce z nowotworami oraz być pomocne dla Ministerstwa Zdrowia, NFZ, AOTM, rządu i parlamentu.

\section{Inicjatywa utworzenia Krajowej Rady ds. Onkologii i Hematologii}

Zdając sobie sprawę, że zasadniczym polem działania $\mathrm{NIOH}$ w sieci onkologicznej oprócz wyżej wymienionych inicjatyw byłaby rola wykonawcza, przejęcie przez Narodowy Instytut audytowania ośrodków onkologicznych, nadzorowania stopnia referencyjności oraz oceny jakości realizowanych w nich świadczeń onkologicznych mogłoby się spotkać — i słusznie — z zarzutem hermetyzacji środowiska onkologicznego, niedostatecznego obiektywizmu, działania w konflikcie interesów czy wręcz monopolizacji onkologii polskiej. Aby wyeliminować te z gruntu niesłuszne i nieuzasadnione opinie i obawy, postuluje się utworzenie Krajowej Rady ds. Onkologii i Hematologii (KROH), jako organu doradczego i opiniodawczego dla ministra właściwego do spraw zdrowia (tab. III), reprezentującej opinie i interesy utworzonej krajowej sieci onkologicznej na bazie $\mathrm{NIOH}$ i WCO oraz ośrodków o 2. i 1. stopniu referencyjności (ryc. 1). Skład KROH ustalałby minister zdrowia, korzystając z grupy konsultantów krajowych, specjalistów z zakresu onkologii klinicznej, hematologii, onkohematologii dziecięcej, radioterapii onkologicznej, chirurgii onkologicznej, medycyny nuklearnej i fizyki medycznej, wytypowanych przez odpowiednie towarzystwa naukowe, w tym PTOK, PTCHO, PTRO, PTO, PTHiT i inne. Dodatkowa obecność przedstawicieli świadczeniodawców, w tym wytypowanych przez Radę Dyrektorów Publicznych WCO (RDPWCO), i ekspertów wskazanych przez organ tworzący (ministra zdrowia) powinna zapewnić obiektywizm i skuteczność podejmowanych przez Krajową Radę inicjatyw i działań (tab. III).

Na podstawie opinii i wniosków KROH to minister zdrowia, a nie $\mathrm{NIOH}$, podejmowałby decyzje i zalecenia audytów w ośrodkach onkologicznych, nadawał stopnie referencyjności i wynikające z nich wskazania dla NFZ odnośnie do liczby i rodzaju świadczeń onkologicznych uprawnionych do realizacji przez indywidualne ośrodki oraz promesy na powstanie nowych ośrodków onkologicznych w regionach zależnie od danych epidemiologicznych i potrzeb tych regionów. Taka trójstruktura: $\mathrm{KROH}, \mathrm{RDPWCO}$ i NIOH stanowiłaby obiektywną i racjonalną bazę dla ministra zdrowia w zakresie oczekiwanych działań i realizacji programu "Czas na onkologię - wspólna sprawa". Wbrew obawom i nieprawdziwym opiniom to $\mathrm{NIOH}$ byłby wykonawcą zadań zalecanych przez KROH i polecanych przez ministra zdrowia, z wyjątkiem inicjatyw naukowych i klinicznych stanowiących podstawę jego działalności statutowej (ryc. 1).

\section{Podsumowanie}

Poprawa leczenia i postęp w walce z nowotworami mogą być uzyskane dzięki właściwej regulacji rynku świadczeń onkologicznych. Poza mechanizmami i narzędziami regulacyjnymi dotyczącymi koszyka świadczeń gwarantowanych oraz wyceną i zasadami finansowania i rozliczania świadczeń onkologicznych konieczne będzie zbudowanie systemu zapewnienia jakości ich udzielania. Zasadniczą rolę w tym systemie powinna odgrywać sieć onkologiczna składająca się z certyfikowanych i okresowo audytowanych ośrodków o 1., 2. i 3. stopniu referencyjności, z organem doradczym (RDPWCO) dla NIOH i Krajowej Rady, pełniącej nie tylko nadzór merytoryczny nad ośrodkami sieci, ale także najważniejszą rolę doradczą i opiniodawczą dla ministra zdrowia. W powszechnej opinii członków RDPWCO i onkologicznych towarzystw naukowych ważnym koordynatorem, inicjatorem i ośrodkiem naukowo-badawczym działającym na rzecz sieci onkologicznej powinien się stać - na wzór wielu krajów UE oraz USA — Narodowy Instytut w Warszawie, utworzony na bazie IHT oraz CO-I wraz z jego oddziałami w Gliwicach i w Krakowie.

Oba Instytuty mają najliczniejszą w kraju grupę samodzielnych pracowników naukowych ze wszystkich dziedzin onkologii i wielu z nich to osoby o uznanej renomie europejskiej i światowej. Ścisła współpraca z czołowymi ośrodkami w Europie i USA jest rękojmią adaptacji w Polsce najnowocześniejszych osiągnięć w zakresie profilaktyki, diagnostyki i skojarzonej terapii nowotworów. Hematologia coraz silniej współdziała w symbiozie z onkologią, a chłoniaki, szpiczaki, białaczki, zespoły mielodysplastyczne, transplantacje krwiotwórczych komórek macierzystych i problematyka leczenia wspomagającego coraz częściej pozostają w polu działania obu dziedzin medycyny. To także racjonalnie przemawia za połączeniem CO-I oraz IHT w jeden instytut.

Koncepcja powołania $\mathrm{NIOH}$ nie zakłada utworzenia instytucji dominującej nad strukturą organizacyjną innych ośrodków onkologicznych. Wprost przeciwnie; ma to być ogniwo spajające działalność sieci onkologicznej, RDPWCO, $\mathrm{KROH}$ i Ministerstwa Zdrowia oraz stanowić kuźnię edukacji specjalistycznej, wdrażania nowoczesnych metod diagnostycznych i terapeutycznych, standardów europejskich w zakresie kontroli jakości i bezpieczeństwa chorych. Z odpowiednio zdefiniowanymi — w ramach konsensusu środowiskowego — zadaniami i kompetencjami ma dążyć do zastąpienia odrębności kooperacją i współdziałaniem. Razem stanowiłyby istotny głos doradczy i opiniotwórczy w podejmowaniu przez Ministerstwo Zdrowia, NFZ, rząd i parlament ważnych i odpowiedzialnych decyzji służących poprawie sytuacji w polskiej onkologii i w pracach nad bu- 
dowaniem racjonalnej i przemyślanej strategii rozwoju tej dziedziny medycyny.

\section{Podziękowania}

Dyrektor Instytutu Hematologii i Transfuzjologii oraz Centrum Onkologii — Instytutu im. Marii Skłodowskiej-Curie i zastępcy w oddziałach w Gliwicach i Krakowie dziękują członkom Rad Naukowych, Pracownikom i większości organizacji związkowych Instytutu Hematologii i Transfuzjologii oraz Centrum Onkologii — Instytutu im. Marii Skłodowskiej-Curie, zwłaszcza oddziałów w Gliwicach i Krakowie, za okazywaną pomoc i wsparcie w staraniach dyrekcji obu instytutów w sprawie powstania Narodowego Instytutu Onkologii i Hematologii. Szczególne wyrazy podziękowania kierujemy do przedstawicieli zarządów onkologicznych towarzystw naukowych wspierających tę inicjatywę w osobach: prof. Macieja Krzakowskiego (Przewodniczącego Polskiego Towarzystwa Onkologii Klinicznej, Konsultanta Krajowego ds. Onkologii), prof. Krzysztofa Składowskiego (Przewodniczącego Polskiego Towarzystwa Radioterapii Onkologicznej), prof. Jacka Fijutha (Przewodniczącego Elekta Polskiego Towarzystwa Onkologicznego), prof. Wojciecha Zegarskiego (Przewodniczącego Polskiego Towarzystwa Chirurgii Onkologicznej), prof. Piotra Rutkowskiego (Przewodniczącego Elekta Polskiego Towarzystwa Chirurgii Onkologicznej), prof. Jerzego Hołowieckiego (Przewodniczącego Stowarzyszenia ds. Leczenia Białaczek u Dorosłych), prof. Sebastiana Giebla (Przewodniczącego Polskiej Grupy Badawczej Chłoniaków). Za wsparcie organizacyjne tworzenia sieci onkologicznej z instytucją koordynującą jej działania, Narodowym Instytutem Onkologii i Hematologii, dziękujemy dr. Zbigniewowi Pawłowiczowi - Przewodniczącemu Rady Dyrektorów Publicznych Wielospecjalistycznych Centrów Onkologii i Dyrektorowi Centrum
Onkologii im. prof. F. Łukaszczyka w Bydgoszczy. Dziękujemy innym Dyrektorom wielospecjalistycznych centrów onkologii deklarujących takie wsparcie w przyszłości, w tym z Białegostoku, Bielska-Białej, Kielc, Łodzi i Wrocławia. Osobom niezdecydowanym przyjąć proponowane rozwiązania dziękujemy za konstruktywne słowa krytyki oraz zachęcamy do zapoznania się z treścią tego artykułu. Zagorzałym przeciwnikom idei powstania Narodowego Instytutu Onkologii i Hematologii także dziękujemy — za Ich niestrudzone, nadzwyczajne i niekonwencjonalne starania zmierzające do unicestwienia projektu — bez tej aktywności nie zyskałby on należnego rozgłosu i tempa prac nad urzeczywistnieniem.

\section{Prof. dr hab. n. med. Krzysztof Warzocha}

Instytut Hematologii i Transfuzjologii

ul. Indiry Gandhi 14, 02-776 Warszawa

e-mail:warzocha@ihit.waw.pl

\section{Piśmiennictwo}

1. http://www.eurocare.it/Portals/0/Protocols/EUROCARE4protocol4Nov04.pdf

2. http://www.europarl.europa.eu/plenary/pl/home.htm

3. Treptow A. Konflikt o kasę dla onkologii. Puls Biznesu 2013; 133: 4

4. Wrzesień A. Czy warto tworzyć superinstytut onkologii? Medical Tribune 2013; 13: 13.

5. http://www.cancer.gov/

6. http://www.nki.nl/

7. http://www.iknl.nl/

8. http://www.e-cancer.fr/

9. http://www.gustaveroussy.fr/

10. http://www.istitutotumori.mi.it/

11. Siedlecki J, Piechutowska A. Sprawozdanie dyrektora z działalności Centrum Onkologii w 2012 roku. Pracownia Poligrafii Centrum Onkologii — Instytutu im. Marii Skłodowskiej-Curie, Warszawa 2013.

12. Warzocha K. 60 lat Instytutu Hematologii i Transfuzjologii. Hematologia 2011; 2 (supl. A): A1-A76.

13. Rudowski W. 60-lecie onkologii Polskiej. Nowotwory 1992; 42: 126-127.

14. Koszarowski T. Urywki wspomnień. Nowotwory 2006; 56 (supl. 3). 